\title{
GLOBOKI HUMANIZEM PROFESORJA PETRA MAYA
}

$\mathbf{P}$ braževanja na Malti in Gozu. O pomenu koncepta vseživljenjskega učenja in izobraževanja, o tem, kako zajeziti neo-liberalizem v izobraževanju odraslih in kako spremeniti šole v skupnostne centre.

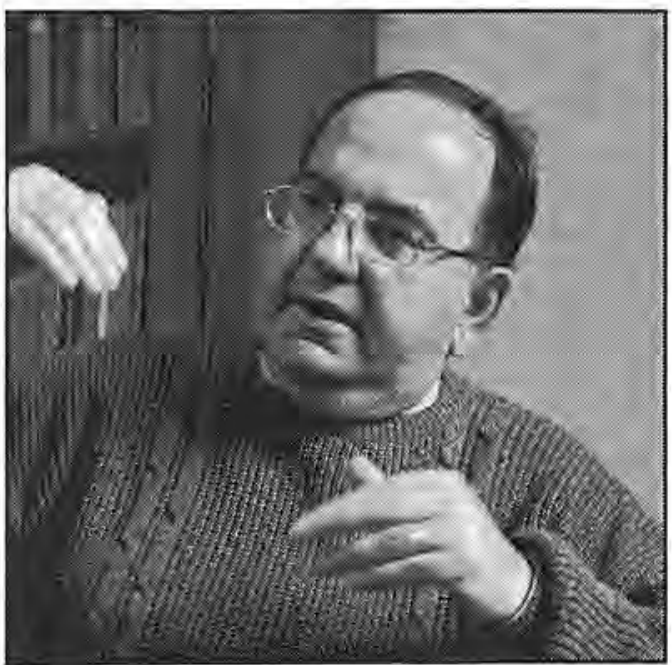

Peter Mayo

(fotografija: Pippa Zammit Cutajar, avtorske pravice: Malta Today)

Profesorja Petra Maya, univerzitetnega učitelja, teoretika izobraževanja odraslih ter družbenega aktivista, srečujem dolga leta na vseh štirih straneh sveta, tokrat pa sva se srečala na Malti, njegovem rodnem otoku. $\mathrm{Na}$ otoku, kjer se zdi sedanjost trdno zasidrana v preteklosti, nikdar ločena od nje. Na preteklost nas tu spominja vse, ne le vojna arhitektura, ki nas obda ob prihodu. Peter Mayo je $\mathrm{v}$ andragoških krogih poznan tudi kot raziskovalec Paola Freira. Ker sem tudi tega teoretika izobraževanja odraslih in družbenega aktivista osebno poznala, je razumljivo, da je najin pogovor sprva stekel o njem. Do vprašanj in odgovorov, ki so predmet tega zapisa, pa sva po tistem prišla neopazno, naravno in domala brez predaha.

Profesor Mayo, dolgo se poznava. Spremljam vaše delo, vem in slutim, da je za vami dolga pot. Pa vendar, ostaniva za zdaj pri tem, kar počnete danes.

Sprašujete me o tem, kje sem danes, kaj počnem, v kaj verjamem? Danes sem izredni profesor na Oddelku za izobraževalne vede, kjer predavam in raziskujem sociologijo izobraževanja in andragogiko. Rad imam teoretske koncepte. Zanima me delo drugih raziskovalcev in izobraževalcev odraslih, pa tudi raznoterih izobraževalnih ustanov. Tako raziskujem Gramscija in Freira. Preučujem, in to mi je $v$ neznansko veselje, izobraževanje delavcev, izobraževanje $v$ muzejih, pokolonialno izobraževanje. Zdi se mi, da je Šle naj se spre-
menijo v skup-
nostne sole in
skupnostne centre! izobraževanje odraslih neizogibno prežeto tudi z lokalnimi značilnostmi in posebnostmi. Tako se posvečam izobraževanju odraslih $\mathrm{v}$ Sredozemlju. Rad razmišljam tudi o vlogi šol in skupnostnih centrov.

$\mathrm{O}$ povedanem sem napisal samostojna dela in članke. Pa še to: kdor predava andragogiko, tako kot vi ali jaz, mora biti blizu ljudem. Tako se občasno še zmeraj prelevim $v$ izo- 
braževalca odraslih ali študenta na seminarjih, ki jih organizirajo nevladne organizacije, politične stranke in državni organi.

Izobraževanje odraslih je lahko družbeno dvigalo. Vpliva na razvoj odraslega pa tudi na povezanost in razvitost družbe. Kako pomembno je v vaših očeh to izobraževanje za razvoj Malte?

Odkar delam na področju izobraževanja odraslih in odkar sem študiral v Kanadi, kjer sem $v$ poznih osemdesetih letih prejšnjega stoletja opravil dodiplomski študij, si prizadevam za to, da bi

Izobraževalne organizacije za odrasle naj sodelujejo v izobraževanju clanov političnih strank. obveljalo spoznanje, da izobraževanje ni le šolanje. S profesorjem Godfreyem Baldacchinom sva napisala delo Onstran solanja. Izobraževanje odraslih na Malti (angl. Beyond Schooling. Adult Education in Malta), Kot lahko sklepate iz naslova, moramo najprej preseči šolanje, da bi kasneje lahko zagledali tisoče drugih načinov, na katere se ljudje učimo, še posebno neformalno učenje. $\mathrm{V}$ nasprotju s šolanjem izobraževanje odraslih ni omejeno s starostjo.

Vendar, ne razumite me napak! Zelo sem naklonjen močni in dobri javni šoli. Kljub vsemu pa si želim, da bi neformalno izobraževanje, ki ustvarja priložnosti za učenje ljudi vseh starosti, imelo več podpore. Le tako bi bilo moč na Malti in Gozu utrditi demokracijo. $\mathrm{Pa}$ še to! Pomembno je uvesti izobraževanje, ki bo iz ljudi naredilo družbene akterje, ne zgolj proizvajalce potrošnike; izobraževanje, ki ne bo samo ozko poklicno, marveč bo zasnovano široko, življenjsko. Prav zato v besedilih in javnih predavanjih zagovarjam zamisel o skupnostnih šlah in skupnostnih centrih. $V$ ta namen moramo preurediti šolske zgradbe, da se bodo $v$ njih srečevali ljudje različnih starosti. Stroški na glavo prebivalca za takšne javne zgradbe so namreč v majhnih državah, kot je Malta, višji za podobne zgradbe $v$ večjih državah. In tako moramo v majhnih državah storiti vse, da bodo šolski prostori služili različnim namenom. Želim se pridružiti skupini, ki pripravlja strategijo razvoja skupnostnih sol. Potrebno je izobraziti tudi skupnostne izobraževalce odraslih.

Želim si družbene pravičnosti in zato tudi delujem na področju izobraževanja odrāslih. Žal se mi zdi, da je danes izobraževanje odraslih preveč poklicno in se preveč podreja potrebam trga. Prảv nič me ne čudi, da se v zadnjih letih uveljavlja izraz učenje namesto izobraževanje, pri čemer je manjši poudarek na organiziranih oblikah izobraževanja odraslih, večji pa na osebni odgovornosti odraslih za učenje. Tako se država lahko izogne odgovornosti. Če potem izobraževanje odraslih ni dovolj uspešno, je zato kriv pač vsakdo sam. Gre za pretkan diskurz, ki načenja vlogo države $v$ izobraževanju in vse prepušča trgu. Nekoč so nam že povedali, da družbe ni, zdaj nam vcepljajo $v$ glavo novo misel, da ni izobraževanja odraslih, ampak le odrasli, ki se učijo. Politične dokumente, ki krepijo in širijo te modne zamisli, bi morali vzeti pod drobnogled. $\mathrm{V}$ moji in drugih državah vse prepogosto te dokumente nekritično sprejemamo.

Kulture naših univerz in dežel se med seboj razlikujejo. Radi se naslonimo tudi na različne teoretske koncepte. Takšne, ki ustrezajo našim vrednotam, prepričanjem, danostim in razvoju našega okolja. Katera je po vašem mnenju temeljna teorija $v$ izobraževanju odraslih na Malti?

Tako kot drugod imamo tudi na Malti več temeljnih teorij, ki jih spoštujemo. Tako kot v vseh državah, na katere vpliva evropska 
politika (tudi Malta se je $v$ maju pridružila Evropski uniji), je tudi pri nas pogosto govor o vseživljenjskem učenju. Pravkar smo pripravili prvi predlog strategije vseživljenjskega učenja in ga želimo dati $v$ javno razpravo. Upamo, da bo razprava plodna. $\mathrm{K}$ sodelovanju bomo poskušali pritegniti široke plasti malteške družbe in njenih organizacij: sindikate, delodajalce, ženske skupine, skupine starejših, različne komisije in organizacije civilne družbe, denimo, društva staršev, študentov ipd.

Takšna široka razprava je seveda potrebna, saj gre za koncepte, ki določajo razvoj vseh družbenih segmentov. Kdo podpira to zamisel?

Razpravo nadzoruje in podpira malteška vlada. Pričakujem, da bo razprava kritična in bo dala krila humanističnemu diskurzu, kakršnega smo poznali nekoč, takrat ko je ta koncept usvojil UNESCO. Več prostora si želim tudi za nekatere alternativne koncepte vseživljenjskega izobraževanja. Koncepte, ki jih prispevajo razmišljujoči in kritični izobraževalci odraslih vseh narodnosti. Resnično upam, da bomo uspeli zajeziti prevladujoče neoliberalne koncepte vseživljenjskega učenja in izobraževanja, ki so preplavili Evropo, Tiste, ki jih zanima le zaposljivost, proizvodnost, opuščajo pa vse druge vidike vseživljenjskega izobraževanja.

Kaj lahko poveste o politiki izobraževanja odraslih na Malti? Ste takšno politiko morda že izdelali?

Ne še, vendar poskušamo! Prizadevamo si za nacionalne strategije vseživljenjskega učenja.

Sindikati naj poskrbijo za plačani študijski dopust; ta pravica naj ne bo mrtva črka na papirju! Izobraževanje odraslih naj postane javna zadeva.
Vse je odvisno od sodelovanja javnosti $v$ načrtovanju teh strategij. Zanimivo bo videti, kdo se bo v razpravo vključil. Seveda pri tem ne smemo pozabiti, da koncept vseživljenjskega učenja in izobraževanja ne zadeva le odraslih, marveč se nanaša na izobraževalno pot ljudi vseh starosti.

Področja izobraževanja odraslih so izjemno raznolika. Funkcionalna pismenost, dopolnilno izobraževanje odraslih, izobraževanje starejših odraslih, izobraževanje za osebnostno rast, visokošolsko izobraževanje za študente ob delu, računalništvo, umetnostna vzgoja, komunikacijske spretnosti in še in še. Čemu danes na Malti dajete prednost?

Večina tega, kar ste navedli, je našla mesto tudi pri nas. Veliko pozornost namenjamo temu, kar evfemistično imenujemo razvoj človeških virov. Veliko potreb je na področju visokošolskega izobraževanja za izredne študente. In iz pridobitnih razlogov smo že v preteklosti pričeli krepiti podobo Malte kot mesta učenja angleščine. To so področja, ki ustrezajo pravladujočemu hegemonističnemu diskurzu. So daleč proč od socialnega izobraževanja odraslih, ki mu sam dajem prednost $v$ svojih predavanjih. Sam sem namreč naklonjen predvsem transformativnim zmožnostim izobraževanja odraslih.

Tistim, ki spreminjajo družbo in okolje. $\mathrm{V}$ osvetlitev te Neformalno izobraževanje ustvarja priložnosti za učenje ljudi vseh starosti.
Rad bi, da bi bilo več kritične zavesti javnosti o politiki izobraževanja odraslih. trditve naj povem, da smo že $v$ začetku osemdesetih let prejšnjega stoletja podpirali razvoj izobraževanja delavcev, saj smo leta 1981 na moji univerzi ustanovili Center za razvoj participacije delavcev in zdaj imamo 
na Malti tudi Sklad Reggija Millerja v okviru Splošnih delavskih sindikatov. Podjetje za izobraževanje in usposabljanje delavcev smo ustanovili leta 1989. Imamo tudi Sklad za izobraževanje staršev in za njihovo sodelovanje $v$ šolah. Sklad za izobraževalne storitve je tudi koordinator projekta Grundtvig na tem področju. Imamo izobraževanje starejših odraslih $\mathrm{z}$ dobro razvito Univerzo za tretje življenjsko obdobje. Dobro razvito je tudi izobraževanje v zaporih in skupnostno izobraževanje.

Našteli ste številna področja izobraževanja odraslih, ki ste jih doslej razvili na Malti. Kolikšen je tedaj delež odraslih, ki se vključujejo v izobraževanje odraslih?

Strinjam se, da bi veljalo poznati številke, vendar doslej še nismo opravili ustrezne nacionalne raziskave. Predstavniki Ministr-

Potrebno je preurediti šolske zgradbe, da se bodo $v$ njih lahko srečevali ljudje vseh starosti. stvà za šolstyo trdijo, da je približno 9000 odraslih sodelovalo $\mathrm{v}$ različnih izobraževalnih oblikah, in sicer od leta 2002 do 2003. Gre za majhno število odraslih, ki živijo na Malti in Gozu, dveh otokih malteškega arhipelaga, na področju katerega danes živi približno 360000 ljudi. Obstajajo komercialni tečaji za "srednji menedžment", računalništvo in nove tehnologije ipd. Te vodi Center za zaposlovanje in usposabljanje (angl. Employment and Training Centre). $\mathrm{Pa}$ tudi izobraževanje odraslih na univerzi je dobro razvito. Seveda imamo tudi veliko prostovoljskih oblik, ki tečejo v lokalnih skupnostih in nevladnih organizacijah, denimo na Inštitutu Paolo Freire, na Akademiji za razvoj demokratičnega okolja (AZAD), ki se povezuje $\mathrm{z}$ vladajočo Nacionalistično stranko, v Skladu Guze Ellul Mercer (GEM), ki je povezan $\mathrm{z}$ malteško laburistično stranko in
Pomembno je uvesti izobraževanje, ki bo iz ljudi naredilo družbene akterje in ne le proizvajalce potrošnike.

delavskimi sindikati. Močni so tudi Splošni delavski sindikati, ki ponujajo več kot sto različnih izobraževalnih oblik ...

Neformalnemu izobraževanju odraslih pogosto zamerijo, da se odvija predvsem na Malti, bolj malo na Gozu. Če želijo obiskovati večerne tečaje, se morajo Gozičani podati čez morje na Malto. Tako porabijo veliko časa in od njih zahteva to veliko napora. Na univerzi smo se zato odločili, da vsaj malo pridemo naproti prebivalcem tega otoka in smo na otoku ustanovili Univerzitetni center za izredne studente.

Izobraževanje odraslih se odziva na spremembe $v$ življenju posameznikov in družbi. Tako je tudi samo podvrženo spremembam. Kakšnih sprememb si vi želite $\mathbf{v}$ malteškem izobraževanju odraslih?

Želim si, da bi izobraževalce odraslih bolje izobrazili. Vse preveč se nam namreč zdi, da se je njihovega dela moč naučiti mimogrede. $\mathrm{Pa}$ ni tako! Res je, da so nekateri izobraževalci izjemno ustvarjalni in intuitivno razvijejo dobre načine. Drugi spet uporabljajo le načine, ki so jih bili deležni v času formalnega izobraževanja. Rad bi tudi, da bi bilo neformalno izobraževanje bolj priznano. Mislim, da bi zato morali več pozornosti posvetiti ocenjevanju in priznavanju nasledkov predhodnega učenja, tj. certifikatnemu sistemu. Paziti bi morali, da ne bi ocenjevali zgolj pridobljenih kompetenc, marveč tudi nasledke drugih vrst učenja. Potrebe odraslih učencev bi se morale zrcaliti v nacionalnih političnih dokumentih in zakonodaji. Še več, rad bi, da bi bilo več kritične zavesti javnosti o politiki izobraževanja odraslih na Malti in Gozu. Ta zavest se zdi 
Nekoč so nam že povedali, da družbe ni. Zdaj nam vcepljajo v glavo novo misel, da ni izobraževanja odraslih in so le odrasli, ki se učijo. Politične dokumente, ki krepijo in šrijo te modne zamisli, bi morali vzeti pod drobnogled.

nadvse potrebna, kajti nedavno se je močno povečala pripravljenost za sodelovanje $v$ evropskih projektih, kot sta Grundtvig in Leonardo da Vinci. Upam, da ponujena denarna sredstva za poklicno izobraževanje ne bodo zaslepila izobraževalcev odraslih in bodo ti nadaljevali $\mathrm{z}$ delom na področju skupnostnega in družbeno naravnanega izobraževanja.

Želim si, da bi se na Malti in Gozu pojavilo več družbenih gibanj. V takšnih gibanjih je namreč največ emancipatornih oblik izobraževanja odraslih. To se zgodi bodisi načrtno ali naključno. Številne izobraževalne organizacije za odrasle sodelujejo $v$ izobraževanju članov političnih strank. Dotikajo se vpraక̌anj, s katerimi se stranka ukvarja. Želim si tudi, da bi moja univerza razvila oddelek za izobraževanje odraslih, ki bi deloval tudi navzven. Mislim, da bo tudi nedavno ustanovljeni Malteški kolidž znanosti, umetnosti in tehnologije odprl takšen oddelek. Prav tako si želim, da bi sindikati uvedli plačani študijski dopust in da bi poskrbeli, da ta pravica ne ostane mrtva črka na papirju. Poskrbeli naj bi, da izobraževanje odraslih postane pomembna javna zadeva. Želim pa tudi, da bi sindikati spodbudili uveljavljanje vseživljenjskega svetovanja.

\section{Povedali ste, kaj vse pričakujete glede izo- braževanja odraslih. Kako pa vidite svojo prihodnost in kakšne načrte imate?}

Želel bi napisati nekaj knjig. Prvo o Gramsciju in izobraževanju odraslih. Pripravljam jo za serijo monografij, ki izhaja $\mathrm{v}$
Veliki Britaniji o tem Sardinijcu, ki se je s političnim delom vključil v izobraževanje. Drugo delo bo nosilo naslov Učenje in družbena različnost. To bo zbirka prispevkov, katerih pisca sva dr. Carmel Borg in jaz. Gre za prispevke, ki sva jih pisala za različne mednarodne revije. V njih je že zdaj čutiti skupno vodilo in mislim, da ne bo tako težko, da jih spremeniva $v$ knjigo. To delo bo čitanka $v$ rabi pri najinih predavanjih na dodiplomskem in podiplomskem študiju. Nameravam tudi sodelovati pri pisanju besedila o kritični pedagogiki za posebno izdajo neke ameriške revije o kulturnih študijah. $\mathrm{Z}$ dr. Carmel Borg pripravljava tudi knjigo intervjujev, ki jo bo izdala založba Peter Lang. V njej bodo sodelovali pisci, univerzitetni učitelji, ki delujejo tudi kot družbeni aktivisti. Hkrati načrtujem pisanje monografije o izobrǎževanju odraslih na Malti. Sem sourednik Revije za pokolonialno izobraževanje (angl. Journal of Post-colonial Education), drugi uredniki so Carmel Borg (Univerza na Malti ), Anne Hickling Hudson (Tehnološka univerza $v$ Queenslandu) in George Sefa Dei (OISE, Univerza v Torontu). Rad bi tudi, da bi se šole spremenile $v$ skupnostne centre, in upam, da bom pri uresničitvi te zamisli lahko sodeloval. $\mathrm{Na}$ fakulteti razvijam nov predmet o skupnostnih šlah in centrih. Gre za osem modulov, od katerih bo sleherni trajal 14 ur. Pri skupnostni šoli gre za vključitev krajanov $v$ šolanje otrok. Gre tudi za uporabo lokalnih virov y dobro šole. Upam, da bomo razvili nove programe za odrasle glede na njihove raznolike potrebe $\mathrm{v}$ okviru izobraževanja odraslih na naši univerzi. Vključen sem tudi v projekt, ki starše uvaja v skupnostno osnovno šolo. Močno si želim, da bi se tudi ta projekt dalje razvijal.

Pogovor in zapis: prof. dr. Ana Krajnc Prevod in priredba: doc. dr. Dušana Findeisen 